\title{
GLOBALIZATION AND ITS IMPACT ON THE THIRD WORLD ECONO-
} MY

\author{
Neelam Kumar Sharma, Ph.D., Asst. Dean \\ Tribhuvan University, Faculty of Humanities \& Social Sciences \\ neelamkumar012@hotmail.com
}

\begin{abstract}
:
Globalization is a controversial issue in the third world countries. This study tries to determine the factors associated with this controversy and explained the economic impacts of globalization in the third world countries on the basis of some of the scholars' arguments expressed on the subject. In the recent past, there have been the pros and cons of globalization in developing countries. Some argue that globalization is indeed a necessary evil to the third world countries that it can neither be rejected nor fully applied to its national policy. However, many others suggest that globalization should be looked at in all its manifestations and from different angles. In order to address this issue, when considered from the economic point of view, the negative economic impacts of globalization should be minimized and exportable capacity of the third world economy in the global market should be increased in a step by step manner.
\end{abstract}

KEYWORDS: Globalization, poverty, inequality, impacts, capitalism, market

\section{INTRODUCTION}

Globalization is the free movement of goods, services and people across the world. In this sense, this kind of global phenomenon is not the same thing as transnational (King 10). Thus, King has clearly stated the process of globalism in terms of not the national, but the global perspective. Economically, globalization is the process of integration of the national economies into the emergent international division of labor. It is a contradictory concept that may be rationale in economics; it may be irrational in other cases.

Some contemporary social theorists, like Hirsch and Thompson, argue that globalization is largely mythical. They explain that nation states retain the capacities to manage national economies, in which globalization is seen as eroding (Shaw 9). It represents the triumph of classicism advocated by Smith and Locke. It is the triumph of democracy, liberalism and capitalism overall other ideology and statecraft (Gill 16). The current focus of economic globalization is the elimination of national borders. In the economically advanced countries, however, these structures precisely reined in market capitalism, making it palatable and acceptable (Ruggie 15-19). This is, indeed, the final stage of open economy started from privatization and economic liberalization.

Globalization, in this study, creates two inter-linked and distinct challenges in developing countries: how can an effective global market be created for them? And what are the political implementation models that can appropriately address the problem of regulating accountability of globalization in the third world countries? 


\section{Crossing the Border: International Journal of Interdisciplinary Studies}

\section{OBJECTIVES}

The general objective of this study is to explain economic impacts of globalization in the third world countries; however, the specific objectives are:

- to assess the definitions of globalization

- to identify third world countries in the global market, and

- to explore the economic impacts of globalization in the third world countries.

\section{DISCUSSIONS}

\section{Economic Consequences of Globalization in the Third World}

Invalidity of Keynesian prescription based on wage-price rigidity for economic adjustment relied mostly on public intervention. This prepared the ground for the rejection of the fixed exchange rate regime in the early 1970s. "The rejection of the state assisted capitalism initially in the 1970s and rigorously in the 1980s gradually paved the way for rapid process of globalization. The initial stage of globalization was economic liberalization. It refers specially to trade and market liberalization whereas globalization is related to open economy weakening the border wall; globalization is unrestricted or initiates easy movement of the factors of production, goods, services, information and technology, same treatment of foreign goods, services, technology together with structural changes in production and employment according to the line and preference of multinational companies (MNCs). As a result, globalization makes the role of state diminish, increases cross border economic interdependence, integrates financial market, rapids the movement of information technology, dominates national policy choice and derives a common culture. Thus, the consequences of globalization policies in the developing nations are as follow (Sharma 118):

\section{Consequences of Globalization Policies}

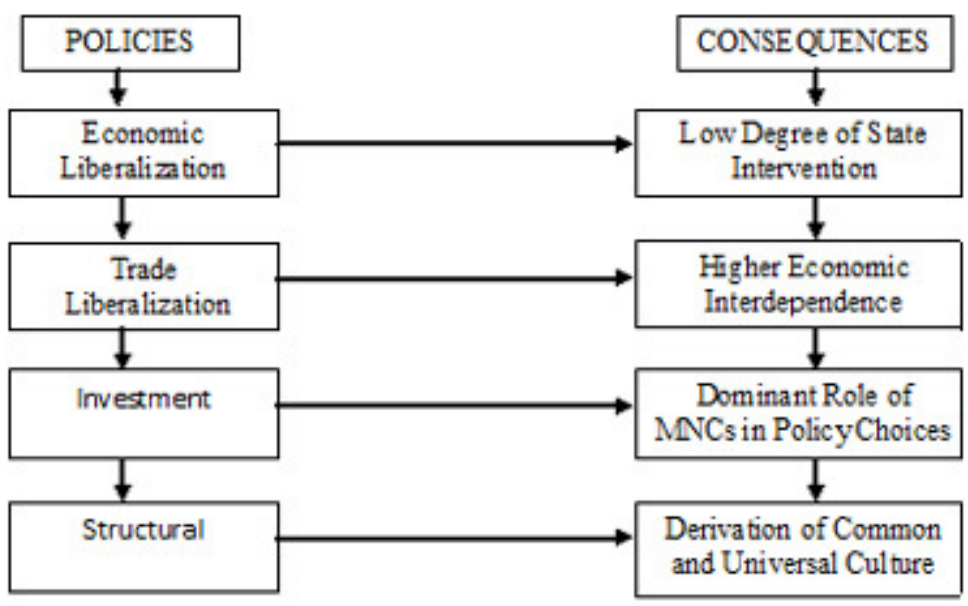

Globalization processes ultimately change the economic structure of the countries in general, and that of the low income nations in particular are overwhelmingly put under the umbrella of the MNCs in technologically advanced countries. In this way, the competition prevails only at the level of multinational companies elsewhere, which are equipped with capital intensive production techniques and similar patterns 


\section{GLOBALIZATION AND ITS IMPACT}

of employment structures. As a result, the formal sector of the economy experiences displacement effect, price effect, capital intensity effect, income inequality effect, lag of social security effect, local governance effect and social effect. In the similar way, the informal sector of the economy experiences delinking effect, capital flight effect and small cottage industries effect.

From an economic perspective, the introduction of the core workers' right is necessary for economic growth and for increasing the efficiency of the concerned national economy. The core workers' rights comprise the ban on forced labor, discrimination, and child labor, and the guarantee of freedom to form associations and the right to collective bargaining between management and labor.

The economic loss of sovereignty and the processes of negative globalization must be overcome by means of positive globalization. This, however, requires the creation of new instruments of regulation. The crucial question, therefore, is: how can global order economically be structured? The answer is not the creation of an ideal, harmonious world republic but rather the 'realistic' intensification of transnational cooperation (Meyer and Breyer 173-77).

Globalization issues, in this sense, have brought people and countries closer and increased their mutual interdependence with higher flow of trade, technologies information and investments fuelling economic progress and creating vast opportunities for human progress. But such progress as enlarged opportunities and interdependence has been quite unbalanced, unequal and unmanaged because of lack of shared values, shared benefits and shared concerns towards those who are marginalized and left behind.

In brief, globalization seems to be more fruitful to the advanced countries and it is ineffective to solve the fundamental problems of the third world. It is clear that globalization and liberalization are unable to solve the fundamental problems of the developing nations such as massive poverty, increasing unemployment and underemployment, lack of social and economic overheads, widespread and multidimensional human deprivations, hunger, social tension, increasing inequality, dislocations of millions of people and so on. If looked back to 1980s, 90s and the first decade of the twenty-first century, all these problems have been found to be associated with manmade crises and environmental degradations, which have been the major issues of today's third world countries since 1980s.

\section{Strategies of Globalization in the Third World}

The great problem of liberalization is that the markets are not economically embedded. This is especially true in financial markets. The existing architecture of the global financial market is largely libertarian, facilitating the rapid acquisition of huge private benefits. Its cost can be catastrophic in terms of prosperity and jobs in isolated or in several affected national economies. As a result, the basic rights of people in these countries are jeopardized (Meyer and Breyer 173-74). Similarly, the next problem of economic globalization has been evolved from the lack of political control over extensively spreading transnational companies which are establishing in several countries. The companies partially evade national fiscal jurisdiction by depositing their profits in countries with more favorable tax systems. Often companies decentralize their production processes to such an extent that individual components are manufactured in countries where it is most advantageous to produce them. 


\section{Crossing the Border: International Journal of Interdisciplinary Studies}

This reduces production costs whereas it weakens the position of the company personnel and even of the national governments in individual production locales. In this context, following five measures of transnational economic regulation have been suggested. Firstly, the balance between political goals and economic action has to be renegotiated at the transnational level. Accordingly, legislation must be enacted to set the limits to market events. Secondly, global actors such as IMF, World Bank, OECD and G-7 should form new economic coordination. For this purpose, an agency must be set up to coordinate economic activities at various regional and global levels. Similarly, the IMF and the World Bank should totally change their policies and global conducive credit conditions for development must be created. Finally, the democratization of decision-making in transnational institutions and the reform of the World Security Council are important steps.

Globalization will empower the convergence of the varieties of capitalism in a liberal model devoid of a welfare state. This ensures protection of basic rights, which does not seem to be valid. It is evident that where institutions for the coordination of markets exist, actors tend to make use of these structures. During the past two decades, coordinated market economies have undergone changes in their structures and mechanisms; they have adapted to the new challenges.

The scope of regulation of the economy has grown significantly since the 1990s because of three general trends. First, the increasing privatization in many countries with lesser role of the state. Second, the transnational market integration that increased gap between the extent of the external effects generated by the markets and the potential for their political regulation. Third, the increment of unforeseeable civilization and environmental risks resulting from unregulated growth processes (Meyer and Breyer 173-75).

\section{Globalization and Inequality in Developing Countries}

Since 1980s, globalization has entered the vocabulary of many people but the concept has given a variety of meanings that remains the subject of debate and controversy. There is an argument about whether or not it is primarily a political, technological, cultural or economic or multi-causal phenomenon; whether it 'pulls upwards' or 'pushes down'; whether it destroys political autonomy or creates new pressures for local autonomy; whether it shrinks the public sphere or demands its enlargement; or whether it enhances or reduces our capacities to understand the world we live in (Mendell 203). So far to focus on economic globalization such as integration of financial markets and other markets, internationalization of production are concerned, 'from 1914 to 1950, however, the world economy experienced lower rates of growth, a retreat from globalization, and economic divergence.' The world economy reversed its surge toward globalization especially after 1990. A number of recent studies have examined globalization's effect on developing countries (Andersen and Kersbergen 197).

During the period from 1973 through the 1980s, inequality rose in the North, in part due to globalization forces. Economic theory and a few studies argue that such rise in inequality would be coupled with a more egalitarian South. The recent widening of wage inequalities in the United States occurred simultaneously with a trend toward trade liberalization and the increased immigration of unskilled workers from developing countries. Borjas has estimated that these forces have contributed 15 to 20 


\section{GLOBALIZATION AND ITS IMPACT}

percent of the relative decrease in the wages of high school graduates compared with college graduates: trade accounting to one-third, and immigration two third. Have these patterns resulted in stimulating the relative demand for unskilled labor in the developing countries and thus made developing countries more egalitarian? "Adrian wood assertions are consistent with economic theory, recent studies show that the number of countries in Latin America and East Asia have experienced increase, not decline, in wage inequality after trade liberalization" (qtd. in Williamson 303).

However, globalization of markets has widened economic inequality and inaugurated a competitive 'race to the bottom' as government seek to attract mobile capital by reducing or eliminating perceived impediments to business, such as relatively high business taxes and relatively entrenched labor rights (Tilly 28). On the other hand, global income and real GDP have risen sevenfold since the end of World War II and threefold in per capita terms, but during that time, the gap in incomes between developed and developing nations continued to widen. In addition, large disparities emerged among developing countries. In this context, Sub-Sahara Africa was the poorest region in the world, where the fundamental issue of human survival remained a grave concern. African nation's real incomes fell or remained stagnant from 1987 to 1994.

The Latin American economies were more unequal relative to other developing regions. Thus, increased inequality in the region was coupled with rising poverty. Economic recovery in the early 1990s boosted the region's growth rates, the real income of the bottom 40 percent remained below the poverty line in most Latin American countries.

In the developing countries, large disparities in inequality and poverty can be attributed to differences in the role of government. Government is associated with the goal of greater equality if income and wealth were coped with the means of redistributive tax and welfare policies (Mendell 203-04). However the most successful East Asian nations have placed on emphasis on poverty alleviation rather than on reduction of inequality (Kim 307-08).

\section{Poverty, Growth and Globalization}

The majority of the poor people live in rural areas of Africa. Lack of political commitment and public support programs for rural development are major hurdles of poverty reduction in this continent. The rural poor people experience very little access to credit, land and extension services. In Latin America, inequality and poverty reflect the legacy of import substitution strategy. This caused Latin American countries to embrace austerity measures in the 1980s, which quickly increased the numbers of critically poor, low paid underemployment and low-wage workers. In addition, market-led growth does not automatically reduce inequality and poverty. Obviously, positive economic growth is not sufficient condition for the reduction of poverty. Moreover, inequality has been observed in many countries. Hence a number of studies point to a strong relationship between equality and growth (Kim 308). This case is not universal that, on average, very little movement toward equality accompanies the process of growth. Moreover, in the 1980s structural adjustment policy gave many countries an additional push toward inequality (Adelman and Fuwa 309-10).

So far as the development and income distribution are concerned, physical and demographic conditions also affect a country's options for development and its in- 


\section{Crossing the Border: International Journal of Interdisciplinary Studies}

come distribution. In addition, natural resources abundance is often associated with inequality. Likewise, greater population density implies less arable land and per agricultural worker. Obviously, less arable land and per agricultural worker are associated with more income inequality.

Economic theory suggests that greater openness to world trade in developing countries will reduce wage inequality. Trade liberalization raises the relative demand for unskilled workers and therefore reduces the wage gap between the skilled and the unskilled. The evidence for East Asia during the 1960s and 1970s supports this theory, but the Latin American's experience since the mid 1980s does not.

When the ratio of skilled to unskilled labor is lower for export than for imports, then increased openness to trade should raise the demand for unskilled workers. The conventional wisdom postulates that increased trade liberalization in developing countries increases the demand for the unskilled relative to skilled labor and thus reduces wage inequality. However, the Latin American experience in the mid-1980s and 1990s challenges this wisdom (Wood 316).

Governments of the third world place their faith in macroeconomic management of largely private economies, combined with measures of redistribution, regional policy, various labor market initiatives, provision of educational opportunity, free health care and social service entitlements (Mendell 203). However, privatization has been a centerpiece of the market-oriented development strategies employed in developing countries over the past three decades. In this framework, the state is an agent of various interest groups, which negotiates the transfer of income and wealth among various factions to the society. Privatization affects the state's ability to control its distributional impact (Cook and Kirkpatrick 323). The extent and generosity of welfare provision also varied from one country to another as did the principles upon which it was founded.

Employment is a core issue for the future of the welfare state for fundamental reasons of social cohesion and individual self-esteem and for reasons of economic sustainability. However, employment is not sufficient to define the aims of social justice. High employment rates are, no doubt, necessary but not a sufficient condition for fair equality of opportunity in society or social inclusion as is shown by comparative figure on poverty (a good yardstick for social exclusion) in the working age population (Vandenbroucke 3). Nevertheless, employment is the major issue in welfare reform, which provides an appropriate route out of poverty.

By ignoring the debate for the moment and focusing on the alleged negative consequences of globalization, we can identify interconnected theses that the powers of national governments have been steadily reduced. (Gray 53). Similarly, Keynesian deficit financing to maintain full employment, which was a central feature of post-war economy, is now inoperable. Growing inequality both within and between nations is, thus, driven by globalization. The rich command internationally determined rates of remuneration; companies seek profits globally; and the unskilled-both low-waged and unemployed are faced with a growing army of cheap labor across the globe (Mendell 203).

\section{CONCLUSION}

Globalization is the final stage of open economy for universal market. In the economic term, it is the process of integration of national economies with interna- 


\section{GLOBALIZATION AND ITS IMPACT}

tional market. In fact, economic globalization is the eliminating process of national borders. It represents the triumph of classical economists like Adam Smith and David Ricardo. In a strict sense, globalization is the extension of market capitalism, which begins with the implementation of privatization policies followed by economic liberalization.

Globalization reduces government's role in the economy and increases economic interdependency among different nations. This interdependency could be beneficial particularly to the advanced countries, which have sufficient exportable capacities with comparatively low cost production techniques. Globalization is not seemed to be an effective measure in the third world to address their fundamental economic challenges such as massive poverty, increasing unemployment, multidimensional human deprivations, starvations, inequality and environmental degradations.

Even though whatever might be the negative economic impacts of globalization, the third world cannot avoid most of the costs of globalization. Therefore, the best strategy is to minimize or mitigate losses. Globalization also opens some opportunities to all developing nations. So, it is suggested to reduce negative economic impacts of globalization. For this, government of the third world nations should work jointly with private sectors to improve supply constraints.

\section{WORKS CITED}

Andersen, Gosta Esping and Kees Van Kersbergen. "Comrarative Research on Social Democracy." Annual Review of Sociology 18 (2009): 197-98. JSTOR. 10 Aug. 2011. $<$ http://www.jstor.org.>.

Adelman, Irma and Nobuhiko Fuwa."Income Inequality and Development: The 1970s and 1980s Compared." The Political Economy of Inequality. Eds. Frank Ackerman and et al. Washington: Island Press, 1995. 309.

Cook, Paul and Colin Kirkpatrick."The Distributional Impact of Privatization in Developing Countries." The Political Economy of Inequality. Eds. Frank Ackerman and et.al. Washington: Island Press, 1995. 323.

Gray, J. After Social Democracy. London: Macmillan, 1996.

Gill, Stephen. American Hegemony. Cambridge: Cambridge University Press, 1990.

King, Anthony, ed. Culture, Globalization and the World System. New York: State University, 1991.

Kim, Kwan S. "Income Distribution and Poverty: An Interregional Comparison." The Political Economy of Inequality. Eds. Frank Ackerman and et.al Washington: Island Press, 2000. 307-08.

Mendell,Marguerite. The Social Economy in Quebec. Montreal: Working Paper, 2003.

Meyer,Thomas and Nicole Breyer. The Future of Social Democracy. New Delhi: FES, 2007.

Ruggie,John Gerard. Constructing the World Polity: Essays on International Institutionalization. London: Routledge, 1998.

Shaw, Martin. "Social Democracy in the Unfinished Global Revolution" 1996: 9. Google. 16 July 2009. <http://www.google.com//socdem.html>.

Sharma, Neelam Kumar. "Development of Social Democratic Economic Thought in Nepal." Diss. Tribhuvan U, 2011. 


\section{Crossing the Border: International Journal of Interdisciplinary Studies}

Tilly, C. "Globalization Threatens Labor Rights" International Labor and Working Class History (Spring 1995). 25-28.

Vandenbroucke, Frank. "Globalization, Inequality and Social Democracy: Summary." 1998. Google. 10 July 2009. <http://www.Google.com//G:/social dem.html>.

Williamson, Jeffery G.. "Globalization and Inequality, Past and Present." The Political Economy of Inequality. Eds. Frank Ackerman and et al. Washington: Island Press, 2000. 303.

Wood, Adrian. "Openness and Wage Inequality in Developing Countries: The Latin American Challenge to East Asian Conventional Wisdom." The Political Economy of Inequality. Eds. Frank Ackerman and et al. Washington: Island Press, 2000. 317. 